\title{
Standarisasi Kepuasan Wisatawan Pengguna Jasa Taman Rusa Lamtanjong Aceh Besar dan beberapa Faktor yang Mempengaruhinya
}

\author{
Nasir $^{1}$, Zakaria $^{2}$, Yuslinaini ${ }^{3}$ \\ ${ }^{1}$ Fakultas Ekonomi, Universitas Serambi Mekkah (USM) \\ ${ }^{2}$ Fakultas Keguruan dan Ilmu Pendidikan, Universitas Serambi Mekkah (USM) \\ ${ }^{3}$ Fakultas Teknologi Pertanian, Universitas Serambi Mekkah (USM)
}

\begin{abstract}
Abstrak. Penelitian ini bertujuan untuk mengetabui sejauh mana kepuasan wisatawan dalam menggunakan jasa wisata Taman Rusa Lamtanjong Aceh Besar, peralatan analilis yang dugunakan adalah regresi linier berganda dengan pengujian reabilitas dan uji validitas, sejaub ini hasil penelitian menunjukkan bahwa semua variabel independen berpengaruh positif terbadap kepuasan konsumen, Dari hasil koefesien regresi faktor bukti fisik menjadi faktor terbesar yang mempengarubi kepuasan wisatawan Taman Rusa Lamtanjong Aceb Besar, kemudian daya tanggap menjadi faktor terendah yang mempengarubi kepuasan konsumen.
\end{abstract}

Kata kunci: kepuasan, wisatawan, pengguna jasa.

\begin{abstract}
This study aims to determine the extent of tourist satisfaction in using the services of the Great Aceh Lamtanjong Deer Park, analytical equipment used is multiple linear regression with reliability testing and validity tests, so far the results of the study indicate that all independent variables have a positive effect on consumer satisfaction, from the results of the regression coefficient the physical evidence factor becomes the biggest factor affecting tourist satisfaction in the Lamtanjong Aceh Besar Deer Park, then responsiveness is the lowest factor affecting consumer satisfaction.
\end{abstract}

Keywords: satisfaction, tourists, service users 


\section{Pendahuluan}

Secara harfiah dan berdasarkan teori kepuasaan konsumen merupakan fondasi dari kualitas layanan diukur melalui lima dimensi kualitas layanan itu sendiri, meliput ireliability, responsive, assurance, emphaty, dan tangible. Reliability menyangkut kehandalan layanan seperti pelayanan yang cepat dan tepat waktu., responsive berhubungan dengan ketanggapan karyawan memberikan layanan, assurance meliputi kepastian layanan, sementara emphaty dan tangible masing-masing berhubungan dengan sikap empati dari karyawan dan kelengkapan fasilitas fisik yang dimiliki penyedia jasa untuk mendukung kelancaran penyerahan jasa itu sendiri.

Fenomena yang terlihat sehubungan dengan sikap wisatawan Taman Rusa Lamtanjong, ada diantara pengguna jasa yang kurang tertarik atau kurang terpuaskan untuk memanfaatkan lokasi Taman Rusa Lamtanjong sebagai lokasi wiasata dimana untuk memilih berlibur di taman ini. Selain letak yang terpencil dan kurangnya tempat bagi pengguna jasa untuk duduk disebabkan banyaknya orang yang berkunjung juga disebabkan keterbatasan dana yang dimiliki untuk menikmati semua wahana bermain yang ada. Tentunya wisatawan yang menggunakan jasa ketika berlibur akan membawa semua keluarga besarnya dan kadangkala ketika pengguna jasa telah membeli satu tiket untuk wahana kolam renang dan melihat wahana bermain lainnya, anak-anak dari pengguna jasa ini ingin mencoba berbagai wahana bermain lainnya, namun dana yang dimiliki oleh pengguna jasa tidak mencukupi untuk memenuhi semua keinginan anak-anak pengguna jasa. Akibatnya, bagi pengguna jasa yang memiliki dana yang cukup tidak akan terjadi masalah, pengguna jasa bisa menikmati semua wahana yang disediakan. Sebaliknya bagi mereka yang tidak mampu tentunya akan memilih tempat wisata lainnya.

Sekalipun ada diantara penggguna jasa yang merasa kecewa, namun masih banyak diantara pengguna jasa yang selalu mendatangi Wisata Taman Rusa Lamtanjong tersebut. Keseringan mereka untuk mendatangi taman rusa, tentunya disebabkan oleh terpenuhi kebutuhan akan pelayanan jasa taman wisata itu sendiri, baik kebutuhan terhadap ketersediaan tempat, pelayanan yang diberikan oleh karyawan taman rusa, maupun terhadap kenyamanan dalam memanfaatkan jasa tersebut.

Fenomena diatas menjelaskan adanya perbedaan kepuasan diantara pengguna jasa dalam memanfaatkan jasa Wisata Taman Rusa Lamtanjong, dimana satu sisi ada pengguna jasa yang merasa kebutuhan mereka akan jasa taman rusa tersebut sudah terpenuhi, dan sisi lain juga banyak diantara mereka yang merasa kebutuhan mereka tidak terpenuhi akibat adanya kekurangan yang mereka rasakan.

\section{Literature Review}

Jasa adalah suatu kinerja penampilan, tidak berwujud dan cepat hilang, fenomena tersebut lebih dapat dirasakan daripada dimiliki. Jasa yang ditawarkan atau diberikan oleh produser akan sangat tergantung kepada penilaian penggunanya. Jasa adalah setiap kegiatan atau manfaat yang ditawarkan oleh suatu pihak pada pihak lain dan pada dasarnya tidak berwujud, serta tidak menghasilkan kepemilikan sesuatu. Proses produksinya mungkin dan mungkin juga tidak dikaitkan dengan suatu produk fisik, Saladin Djaslim (2004:134).

Menurut Zeithaml dan Bitner yang dikutif oleh Hurriyati Ratih (2005:28) pengertian jasa adalah seluruh aktivitas ekonomi dengan output selain produk dalam pengertian fisik, dikonsumsi dan diproduksi pada saat bersamaan, memberikan nilai tambah dan secara prinsip tidak berwujud (Intangible) bagi pembeli pertamanya. Kothler (2007:30) menyatakan bahwa sebagai pelanggan adalah perasaan senang atau kecewa yang seseorang muncul setelah membandingkan antara kinerja (hasil) produk yang dipikirkan terhadap kinerja atau hasil yang diharapkan. Jika kinerja berada di bawah harapan, pelanggan tidak puas. Jika kinerja memenuhi harapan pelanggan puas. Jika kinerja melebihi harapan, pelanggan amat puas atau senang.

Dalam buku Costumer Behavior, Engel (2002:210) mendefenisikan bahwa kepuasan adalah sebagai evaluasi purna beli bahwa suatu alternative yang dipilih tersebut setidaknya memenuhi atau melebihi harapan, jadi alternatif tersebut 
setidaknya bekerja memenuhi atau melenihi harapan, Berdasarkan pendapat di atas dapat disimpukan bahwa yang dimaksud dengan kepuasan adalah yaitu tingkat cepat perasaan seseorang setelah membandingkan performansi (atau hasil) yang ia rasakan dibandingkan dengan harapannya. Jadi tingkat kepuasan merupakan fungsi dari perbedaan antara kinerja yang dirasakan dengan harapannya. Apabila kinerja dibawah harapan, maka konsumen akan kecewa. Bila kinerja sesuai dengan harapan, konsumen akan puas. Sedangkan bila kinerja melebihi harapan, konsumen akan sangat puas. Harapan konsumen dapat dibentuk oleh pengalaman masa lampau, komentar dari kerabatnya serta janji dan informasi pemasar dan sainganya. Konsumen yang puas akan setia lebih lama, kurang sensitive terhadap harga dan member komentar yang baik tentang perusahaan.

\section{Konsep Kepuasan Pelanggan Berdasarkan Perspektif Psikologi Model Kognitif}

Pada model ini penilaian pelanggan didasarkan pada perbedaan antara suatu kumpulan dari kombinasi atribut yang dipandang ideal untuk individu dan persepsinya tentang kombinasi atribut yang sebenarnya. Dengan kata lain, penilaian tersebut didasarkan pada selisih atau perbedaan antara yang ideal dengan yang aktual. Apabila yang ideal sama dengan yang sebenarnya (persepsinya atau yang dirasakannya), maka pelanggan akan sangat puas terhadap produk atau jasa tertentu. Sebaliknya, bila perbedaan antara yang ideal dan yang sebenarnya atau yang dipersepsikan itu semakin besar, maka pelanggan itu semakin tidak puas. Jika perbedaan semakin kecil, maka besar kemungkinannya pelanggan yang bersangkutan akan mencapai kepuasan.

Persepsi individu terhadap kombinasi atribut dari atribut yang ideal tergantung dari daur hidupnya, pengalaman atas produk atau jasa, dan harapan serta keluhannya. Jadi indeks kepuasan pelanggan dalam model kognitif mengukur perbedaan antara apa yang diwujudkan perusahaan berdasarkan modal ini, maka kepuasan pelanggan dapat dicapai dengan dua cara utama, yaitu: 1) Mengubah penawaran perusahaan sehingga sesuai dengan yang ideal, dan 2) Menyakinkan pelanggan bahwa ideal tidak sesuai dengan kenyataan. Beberapa model kofnitif (Tjiptono, 2000:32) yang sering dijunpai antara lain; The Expectency Discomfirmation Model, Berdasarkan model ini kepuasan pelanggan ditentukan oleh dua variable kognitif, yakni harapan para pembelian (prepurchase expectation) yaitu keyakinan kinerja yang diantisipasi dari suatu produk atau jasa dan discomfirmation yaitu perbedaan antara harapan para pembelian dan persepsi purna beli (posi-prepurchase perception.

Model Efektif, menyatakan bahwa penilaian pelanggan individual terhadap suatu produk dan jasa tidak semata-mata berdasarka perhitungan rasional, namun juga berdasarkan kebutuhan subjektif, aspirasi dan pengalaman. Fokus utama model efektif lebih dititik beratkan pada tingkat aspirasi, prilaku belajar, emosi, perasaan spesifik (apresiasi, kepuasaan, keengganan dan lain-lain). Maksud dari fokus ini adalah agar dapat dijelaskan dan diukur tingkat kepuasan dalam suatu kurun waktu (longitudinal).

\section{Konsep Kepuasan Pelanggan Berdasarkan Perspektif Total Quality Management (TQM)}

Total Quality Management (TQM) merupakan suatu pendekatan dalam menjalankan bisnis yang mencoba untuk memaksimumkan daya saing organisasi melalui perbaikan secara berkesinambungan atas produk, jasa, manusia, proses dan lingkungannya. Sistem manajemen TQM berlandaskan pada usaha mengangkat kualitas sebagai strategi usaha dan berorientasi pada kepuasan pelanggan dengan melibatkan seluruh anggota organisasi (Tjiptono, 2000:32). Goetsch dan Davis (2002:29) dalam membuat karakteristik utama dari TQM antara lain meliputi: (1) Fokus pada pelanggan, baik internal maupun eksternal. (2) Memiliki obsesi yang tinggi pada kualitas. (3) Menggunakan pendekatan ilmiah dalam mengambil keputusan dan pemecahan masalah. (4) Memiliki komitmen jangka panjang. (5) Membutuhkan kerja sama tim. (6) Memperbaiki proses secara berkesinambungan. (7) Menyelenggarakan pendidikan dan pelatihan. (9) Memberikan kebebasan yang terkendali. (10) Memiliki kesatuan tujuan. (11) Adanya keterlibatan dan pemberdayaan karyawan. Dasar utama dari pendakatan TQM adalah bahwa kualitas organisasi ditentukan oleh para pelanggan. Dengan demikian prioritas utama dalam jaminan 
kualitas adalah piranti yang handal dan shahih tentang penilaian pelanggan terhadap perusahaan.

Kualitas jasa sering didefinisikan sebagai usaha pemenuhan dari keinginan pelanggan serta ketepatan penyampaian jasa dalam rangka memenuhi harapan pelanggan. Menurut Wyckof dalam Tjiptono (2000: 260) berpendapat bahwa Kualitas jasa merupakan tingkat keunggulan (exellence) yang diharapkan dalam pengendalian atas keunggulan tersebut untuk memenuhi keinginan pelanggan. Pengaruh kualitas jasa terhadap loyalitas telah dibuktikan oleh hasil penelitian Sabihaini (2002) dalam Sinaga, (2010:35) yang menyimpulkan bahwa peningkatan kualitas jasa akan memberikan dampak yang baik untuk meningkatkan loyalitas. Dizaman yang semakin maju, dengan semakin banyaknya informasi, selain menjadi lebih pandai, calon konsumen semakin berhati-hati dalam menggunakan uangnya untuk berbelanja. Ketika calon konsumen memutuskan untuk membeli atau mengkonsumsi sesuatu, semakin banyak aspek atau kriteria yang dipertimbangkan, termasuk salah satunya ialah kualitas produk dan jasa yang akandikonsumsi. Lima indikator kualitas yang di pertimbangkan oleh konsumen Tjiptono, (2008:68) adalah:

1. Bukti langsung (tangibles), meliputi fasilitas fisik, perlengkapan, pegawai dansarana komunikasi. Contohnya, fasilitas reparasi dan ruang tunggu yang representative.

2. Keandalan (reliability), yaitu kemampuan memberikan pelayanan yang dijanjikan dengan segera, akurat dan memuaskan. Contoh keandalan pada bidang jasa pemrosesan informasi yaitu, menyediakan informasi yang dibutuhkan pada saat diminta.

3. Daya tanggap (responsiveness), yaitu keinginan dan kesediaan parastaf/ karyawan untuk membantu para pelanggan dan memberikan pelayanan dengan tanggap.

4. Jaminan (assurance), mencakup pengetahuan, kemampuan, kesopanan dansifat dapat dipercaya yang dimiliki para staf/ karyawan, bebas dari bahaya dan risiko atau keragu-raguan.
5. Empati, meliputi kemudahan dalam menjalin hubungan, komunikasi yang baik dan efektif, perhatian personal dan pemahaman atas kebutuhan individual para pelanggan.

Kelima indikator kualitas pelayanan adalah ciri, karakteristik atau sifat suatu produk atau pelayanan yang berpengaruh pada kemampuan untukmemuaskan kebutuhan konsumen. Konsumen yang merasa terpuakan akanmelakukan pembelian ulang yang menimbulkan loyalitas pelanggan. Dalam meningkatkan kualitas jasa, banyak faktor yang perlu dipertimbangkan dan upaya tersebut juga berdampak luas terhadap budaya organisasi secara keseluruhan. Faktor-faktor yang perlu mendapat perhatian menurut (Tjiptono, (2000:88), mengidentifikasi determinan utama kualitas jasa, mengelola harapan pelanggan, mengelola bukti kualitas jasa yang bertujuan untuk memperkuat persepsi pelanggan selama dan sesudah jasa diberikan, mendidik konsumen tentang jasa (membantu pelanggan dalam memahami suatu jasa), mengembangkan budaya kualitas, menciptakan Automating Quality, menindaklanjuti jasa dalam membantu memisahkan aspek-aspek jasa yang perlu ditingkatkan, mengembangkan Sistem Informasi Kualitas Jasa.

Kothler (2007:138) mengidentifikasikan metode untuk mengukur kepuasan pelanggan yaitu;

1. Complaint and Suggestion System (sistem keluhan dan saran), Setiap organisasi yang berorientasi pada pelanggan perlu memberikan kesempatan yang luas kepada para pelanggannya untuk menyampaikan saran, pendapat dan keluhan mereka. Media yang digunakan bisa berupa kotak saran, yang diletakkan di tempat-tempat strategis (yang mudah dijangkau atau dilewati pelanggan), kartu komentar (yang diisi langsung maupun dikirim via pos kepada perusahaan), saluran telepon khusus bebas pulsa, dan lain-lain. Informasi-informasi yang diperoleh melalui metode ini dapat memberikan ide-ide baru dan masukan yang berharga pada perusahaan, sehingga memungkinkan perusahaan untuk bereaksi dengan tanggap dan cepat dalam mengatasi masalah-masalah yang timbul. Akan tetapi, 
karena metode ini bersifat pasif, maka sulit untuk mendapat gambaran lengkap mengenai kepuasan atau ketidakpuasan pelanggan. Tidak semua pelanggan yang tidak puas akan menyampaikan keluhannya, bisa saja mereka langsung beralih pemasok dan tidak akan membeli produk perusahaan itu lagi. Upaya mendapatkan saran yang bagus dari pelanggan juga sulit diwujudkan dengan metode ini. Terlebih lagi bila perusahaan tidak memberikan timbal balik dan tindak lanjut yang memadai kepada mereka yang telah bersusah payah berfikir menyumbangkan ide kepada perusahaan.

2. Survey kepuasan pelanggan, Umumnya banyak penelitianmengenai kepuasaan yang dilakukan dengan penelitian survey, baik dengan survey melalui pos, telepon, maupun wawancara pribadi. Melalui survey perusahaan akan memperoleh tanggapan dan umpan balik secara langsung dari pelanggan dan juga memberikan tanda positif bahwa perusahaan menaruh perhatian terhadap para pelanggannya.

3. Ghost Shopping, Salah satu cara untuk memperoleh gambaran mengenai kepuasan pelanggan adalah dengan memperkerjakan beberapa orang (ghost shopper) untuk berperan atau bersikap sebagai pelanggan/pembeli potensial produk perusahaan dan pesaing. Kemudian mereka melaporkan teman-temannya mengenai kekuatan dan kelemahan produk perusahaan dan pesaing berdasarkan pengalaman mereka dalam pembelian produk-produk tersebut. Selain itu, para ghost shopper tersebut juga dapat mengamati cara perusahaan dan pesaingnya melalui permintaan pelanggan, menjawab pertanyaan pelanggan dan menangani setiap keluhan.

4. Lost Customers Analysis, Perusahaan sebaiknya menghubungi para pelanggan yang telah berhenti membeli atau telah pindah pemasok agar dapat memahami mengapa hal itu terjadi dan supaya dapat mengambil keputusan perbaikan atau penyempurnaan selanjutnya. Bukan hanya exit interview saja yang perlu, tetapi customers lost rate juga penting, dimana peningkatan customers loss rate menunjukkan kegagalan perusahaan dalam memuaskan pelanggannya.

Selanjtnya metode survey kepuasan pelanggan Kothler (2007:138) dapat menggunakan pengukuran berbagai cara sebagai berikut:

1. Directly Reported Satisfaction, Pengukuran dapat dilakukan secara langsung dengan pertanyaan seperti seberapa puas pelanggan terhadap pelayan perusahaan pada skala berikut: sangat tidak puas, tidak puas, nertal, puas, sangat puas.

2. Derived Satisfaction, Pelanggan diberi pertanyaan mengenai seberapa besar mereka mengharapkan suatu atribut tertentu dan seberapa besar yang mereka rasakan.

3. Problem Analysis, Pelanggan diminta untuk menuliskan masalah-masalah yang mereka hadapi berkaitan dengan penawaran dari perusahaan dan jasa diminta untuk menuliskan perbaikan-perbaikan yang mereka sarankan.

4. Importance/Performance, Pelanggan diminta untuk merangkum berbagai elemen (atribut) dari penawaran berdasarkan derajat pentingnya setiap elemen dan seberapa baik kinerja perusahaan dalam masing-masing elemen.

Keberhasilan suatu kegiatan pariwisata sangat ditentukan oleh tingkatkualitas pelayanan yang diberikan kepada para wisatawan, karena kualitaspelayanan dipercaya sangat berbanding lurus dengan kepuasan wisatawan, dan jika kepuasan wisatawan terpenuhi diharapkan apresiasi dalam upayamemperbaiki tata cara pelayanan dapat menjadi lebih baik.

\section{Metodologi Penelitian}

Penelitian ini hanya dikaji tentang faktor-faktor yang mempengaruhi kepuasan pengguna jasa pada wisata taman rusa lamtanjong, khususnya yang berkaitan dengan kualitas pelayanan yang mencakup lima unsur yaitu kehandalam, responsive berhubungan dengan ketanggapan karyawan memberikan layanan, assurance meliputi kepastian layanan, sementara emphaty dan tangible masingmasing berhubungan dengan sikap empati dari karyawan dan kelengkapan fasilitas fisik yang dimiliki penyedia jasa untuk mendukung kelancaran penyerahan jasa itu sendiri. 
Penentuan jumlah sampel didasarkan pada metode convenience sampling dan diambil secara acak sebanyak 100 orang, Teknik pengumpulan data yang digunakan oleh penulis adalah sebagai berikut:

Untuk menganalisis data dalam mengetahui faktor-faktor yang berpengaruh pada kepuasan pengguna jasa maka dapat dirumuskan bahwa kepuasaan pengguna jasa terhadap wisata taman rusa Lamtanjong merupakan fungsi dari beberapa faktor. Bertitik tolak pada landasan teoritis yang telah dikemukakan pada bab sebelumnya, pada dasarnya kepuasaan konsumen yang dalam hal ini adalah masyarakat sebagai pengguna jasa wisata taman rusa Lamtanjong, dipengaruhi oleh kualitas pelayanan yang diberikan oleh sumber jasa yang dalam hal ini adalah pihak pengelola taman wisata itu sendiri. Karena itu, secara lebih khusus dapat dirumuskan bahwa kepuasan pengguna jasa merupakan fungsi dari faktor kualitas pelayanan, yang meliputi kehandalan (Reliability), daya tanggap (Responsiveness), jaminan (Assurance), empati (Emphaty), dan bukti fisik (Tangible).

Mengacu pada uraian di atas, maka peralatan analisis data yang dinilai cocok untuk menjelaskan keterkaitan antara faktor-faktor kualitas pelayanan sebagai variable penjelas terhadap kepuasan pengguna jasa, adalah regresi linier berganda. Penggunaan analisis regresi linier berganda sebagai alat analisis data membutuhkan perhitungan matematis didalamnya. Skala pengukuran yang digunakan minimal berskala interval. Jika data yang dianalisis berskala ordinal sebagaimana halnya skala likert, maka terlebih dahulu harus ditransformasikan ke dalam bentuk skala interval agar dapat digunakan untuk analisis regresi (Waryanto dan Milifati, 2009: 29). Hal ini didukung oleh pendapat Suliyanto (2007:83) yang menyatakan, tingkat pengukuran data dalam skala likert adalah ordinal sehingga apabila akan dianalisis dengan statistik parametrik harus dinaikkan terlebih dahulu menjadi skala interval. Dengan demikian langkah-langkah yang digunakan dalam menganalisis data dapat dijelaskan sebagai berikut.
Mentabulasikan data kueseioner berdasarkan skor/skala likert. Alternative pilihan jawaban responden terhadap masing-masing pernyataan ditabulasikan dalam bentuk skala likert, mengacu pada skala pengukuran data. peralatan analisis data yang digunakan adalah regresi linier berganda. dengan formula sebagai berikut. $Y=a+b_{1} \mathrm{X}_{1}+\mathrm{b}_{2} \mathrm{X}_{2}+\mathrm{b}_{3} \mathrm{X}_{3}+\ldots+\mathrm{b}_{\mathrm{n}} \mathrm{X}_{\mathrm{n}}+\mathrm{e}$

Untuk kepentingan penelitian, maka persamaan regresi berganda tersebut dirumuskan sebagai berikut.

$$
\begin{aligned}
& Y=a+b_{1} \mathrm{X}_{1}+\mathrm{b}_{2} \mathrm{X}_{2}+\mathrm{b}_{3} \mathrm{X}_{3}+\mathrm{b}_{4} \mathrm{X}_{4}+\mathrm{b}_{5} \mathrm{X}_{5}+\mathrm{e} \\
& \text { Dimana: } \\
& \mathrm{Y} \quad=\text { Tingkat kepuasaanpengguna } \\
& \text { jasa } \\
& A \quad=\text { Konstanta } \\
& \mathrm{X}_{1} \quad=\text { Factor kehandalan (Reliability) } \\
& \mathrm{X}_{2} \quad=\text { Factor ketanggapan } \\
& \text { (Responsiveness) } \\
& \mathrm{X}_{3}=\text { Factor keyakinan (Assurance) } \\
& \mathrm{X}_{4} \quad=\text { Factor empati (Emphaty) } \\
& \mathrm{X}_{5} \quad=\text { Factor keterwujudan } \\
& \text { (Tangible) } \\
& \mathrm{B}_{1}, \mathrm{~b}_{2}, \mathrm{~b}_{3},=\text { koefisien regresi } \mathrm{X}_{1}, \mathrm{X}_{2}, \mathrm{X}_{3}, \mathrm{X}_{4} \text {, } \\
& \mathrm{b}_{4} \text {, dan } \mathrm{b}_{5} \quad \text { dan } \mathrm{X}_{5}
\end{aligned}
$$

Untuk mencari keeratan hubungan antara kelima faktor kualitas pelayanan dengan kepuasaan pengguna jasa terhadap wisata taman rusa Lamtanjong digunakan koefisien korelasi (r). selanjutnya untuk melihat besarnya pengaruh kelima faktor kualitas pelayanan terhadap kepuasan pengguna jasa digunakan koefisien determinasi $\left(\mathrm{r}^{2}\right)$.

\section{Pengujian Reliabilitas}

Keandalan suatu pengukuran menunjukan sejauh mana pengukuran tersebut tanpa bias (bebas kesalahan) dan karena itu menjamin pengukuran yang konsisten lintas waktu dan lintas beragam item dalam instrumen. Dengan kata lain, "keandalan suatu pengukuran merupakan indikasi mengenai stabilitas dan konsistensi dimana instrument mengukur konsep dan membantu menilai ketepatan sebuah pengukuran (Sekaran, 2006:40). Dalam penelitian ini, tolak ukur reliabilitas suatu kuesioner adalah nilai alfa cronbach yang diperoleh melalui perhitungan statistik. Ma'ruf (2005:96), menyatakan nilai alfa cronbach minimum yang dapat diterima adalah 0,60 . Hal ini berarti suatu 
kuesioner dinyatakan handal apabila nilai alfa cronbach yang diperoleh diatas 0,60 ".

\section{Penguijan Validitas}

Suatu skala pengukuran disebut valid apabila ia melakukan apa yang seharusnya dilakukan dan mengukur apa yang seharusnya diukur. Penentuan validitas dapat dilakukan dengan mencari nilai korelasi skor masing-masing item dengan skor total item untuk setiap variabel. Kemudian nilai $r$ hitung yang diperoleh dari korelasi tersebut dibandingkan dengan nilai $r$ tabel pada tingkat keyakinan 99 persen, dengan ketentuan $\mathrm{r}$ hitung $>\mathrm{r}$ tabel maka item pernyataan tersebut dinyatakan valid. Sebaliknya apabila nilai $r$ hitung $<\mathrm{r}$ tabel maka item pernyataan tersebut tidak valid (Suliyanto, 2006:149).

\section{Hasil dan Pembahasan}

\section{Karakteristik Responden}

Berdasarkan hasil survei lapangan terhadap 100 orang responden maka dapat diidentifikasi karakteristik responden penelitian seperti dilihat dari jenis kelamin, umur, status perkawinan, tingkat pendidikan dan besarnya penghasilan, pekerjaan dan rata-rata lama tinggal responden seperti tersaji pada tabel 1 sampai tabel 5.

Tabel 1. Karakteristik Responden Berdasarkan Jenis Kelamin

\begin{tabular}{llcc}
\hline No & $\begin{array}{c}\text { Jenis } \\
\text { kelamin }\end{array}$ & $\begin{array}{c}\text { Jumlah } \\
\text { wisatawan }\end{array}$ & $\begin{array}{c}\text { Kontribusi } \\
(\%)\end{array}$ \\
\hline 1. & Laki-laki & 62 & 62,0 \\
2. & Wanita & 38 & 38,0 \\
\hline & Jumlah & 100 & 100 \\
\hline
\end{tabular}

Sumber : Hasil penelitian (Diolah) 2018

Karakteristik responden berdasarkan jenis kelamin tersaji pada tabel 1 yang menunjukkan bahwa respondenlaki-laki dengan jumlah wisatawan 62 lebih dominan $(62,0 \%)$ dibandingkan respondenperempuan jumlah wisatawan 38 sebesar $(38,0 \%)$.
Tabel 2. Karakteristik Responden Berdasarkan Umur

\begin{tabular}{llcc}
\hline No & Umur & $\begin{array}{c}\text { Jumlah } \\
\text { wisatawa }\end{array}$ & $\begin{array}{c}\text { Persentase } \\
(\%)\end{array}$ \\
\hline 1. & $<15$ tahun & 28 & 28,0 \\
2. & $15-25$ tahun & 26 & 26,0 \\
3. & $25-35$ tahun & 31 & 31,0 \\
4. & $35-45$ tahun & 10 & 10,0 \\
5. & $>50$ tahun & 5 & 5,0 \\
\hline & Jumlah & 100 & 100
\end{tabular}

Sumber : Hasil penelitian (Diolah) 2018

Karakteristik responden dilihat berdasarkan umur tersaji pada tabel 2 Umur responden dapat dikelompokkan dan dari hasil pengelompokkan terlihat kelompok terbesar responden adalah yang berumur 25 sampai 35 tahun $(31,0 \%)$ sedangkan kelompok terkecil berasal dari umur di atas sampai 45 tahun (5,0\%). Umur bisa menentukan tingkat kedewasaan seseorang sehingga hal ini bisa mempengaruhi dalam perilakunya dan cara pemikirannya.

Tabel 3. Karakteristik Responden Tingkat Pendidikan Terakhir

\begin{tabular}{llcc}
\hline & $\begin{array}{c}\text { Tingkat } \\
\text { Pendidikan }\end{array}$ & $\begin{array}{c}\text { Jumah } \\
\text { Wisatawan }\end{array}$ & $\begin{array}{c}\text { Persentase } \\
(\%)\end{array}$ \\
\hline 1. & SD & 20 & 20,0 \\
2. & SMP & 22 & 22,0 \\
3. & SMA & 28 & 20 \\
4. & Diploma & 18 & 18,0 \\
5. & Sarjana & 12 & 12,0 \\
\hline & jumlah & 100 & 100 \\
\hline
\end{tabular}

Sumber : Hasil penelitian (Diolah) 2018

Karakteristik responden berdasarkan tingkat pendidikan tersaji pada tabel 3 yang menunjukkan bahwa responden yang berpendidikan SMA yang terbanyak yaitu $(28,0 \%)$, sementara yang berpendidikan Sarjana jumlahnya lebih sedikit yaitu $(12,0 \%)$. Tingkat pendidikan yang ditempuh seseorang menunjukkan tingkat pengetahuan dan wawasan yang dimiliki, yang akan berpengaruh pada kemampuan analistis terhadap suatu permasalahan seperti pelayanan yang diberikan oleh Wisata Taman Rusa Lamtanjong. 
Tabel 4. Karakteristik Responden Berdasarkan Pekerjaan

\begin{tabular}{llll}
\hline No & $\begin{array}{l}\text { Jenis } \\
\text { Pekerjaan }\end{array}$ & $\begin{array}{l}\text { Jumah } \\
\text { Wisatawan }\end{array}$ & $\begin{array}{l}\text { Persentase } \\
(\%)\end{array}$ \\
\hline 1. & Pelajar & 29 & 29,0 \\
2. & Swasta & 27 & 27,0 \\
3. & Buruh & 19 & 19,0 \\
4. & PNS & 20 & 20,0 \\
5 & TNI/POLRI & 5 & 5,0 \\
\hline & jumlah & 100 & 100 \\
\hline
\end{tabular}

Sumber : Hasil penelitian (Diolah) 2018

Karakteristik responden berdasarkan pekerjaan disajikan pada tabel 4 yang menunjukkan bahwa responden yang bekerja sebagai pelajar lebih sebesar sebanyak $29,0 \%$, sementara responden yang bekerja sebagaiTNI/POLRI jumlahnya lebih sedikit, yaitu 5,0\%. Dari hasil tersebutmenunjukkan para wisatawan memang kebanyakan dari mereka yang belum bekerja di bandingkan dengan yang sudah bekerja.

\section{Pembahasan}

Keandalan terhadap Kepuasan Konsumen wisatawan. Keandalan berpengaruh signifikan terhadap kepuasan wisatawan. Hasil temuan ini sesuai dengan hasil penelitian Assegaff (2009), Atmawati dan Wahyuddin (2007) serta Schroeder (2005). Keandalan merupakan kemampuan memberikan pelayanan yang dijanjikan dengan segera, akurat dan memuaskan oleh manajemen Taman Rusa Lamtanjong Kabupaten Aceh Besar, seperti ketepatan waktu bila berjanji, waktu pelayanan memadai, kecepatan dalam pemberian layanan, keramahan dan sikap suka menolong dan prosedur pelayanan yang tidak berbelit-belit. Hal ini berarti taman memberikan jasanya secara tepat semenjak saat pertama. Keandalan disini merupakan sejauh mana para karyawan bisa secara cepat tanggap dalam memahami dan mengatasi permasalahan yang dihadapi oleh para pelanggan. Semakin andal hasil diperlihatkan oleh para karyawan maka permasalahan yang dihadapi oleh para pelanggan akan cepat terselesaikan. Semakin tinggi tingkat keandalan Taman Rusa Lamtanjong Kabupaten Aceh Besar, maka akan mempengaruhi kepuasan wisatawan.

\section{Daya Tanggap terbadap Kepuasan Wisatawan}

Daya tanggap berpengaruh signifikan terhadap kepuasan pelanggan konsumen wisatawan Taman Rusa Lamtanjong.Hasil temuan ini sesuai dengan hasil penelitian Assegaff (2009), Atmawati dan Wahyuddin (2007) serta Schroeder (2005). Daya tanggap merupakan keinginan para karyawan Taman Rusa Lamtanjong Kabupaten Aceh Besar untuk membantu para pelanggan dan memberikan pelayanan dengan tanggap, seperti siap membantu pelanggan, kecepatan dalam pelayanan dan komunikasi yang lancar. Daya tanggap disini dapat berarti respon atau kesigapan karyawan dalam membantu pelanggan dan memberikan pelayanan yang cepat. Semakin tinggi daya tanggap yang diperlihatkan oleh para karyawan maka permasalahan yang dihadapi oleh para pelanggan akan cepat terselesaikan. Semakin tinggi tingkat daya tanggap Taman Rusa Lamtanjong Kabupaten Aceh Besar, maka akan mempengaruhi kepuasan pelanggan.

\section{Jaminan terhadap Kepuasan Konsumen}

Jaminan berpengaruh signifikan terhadap kepuasan pelanggan wisatawan sebagai konsumen pengguna jasa wisata Lamtanjong Aceh Besar. Hasil temuan ini sejalan dengan hasil penelitian Assegaff (2009), Atmawati dan Wahyuddin (2007) serta Schroeder (2005). Jaminan merupakan pengetahuan, kemampuan, kesopanan, dan sifat dapat dipercaya yang dimiliki para karyawan Taman Rusa Lamtanjong Kabupaten Aceh Besar untuk membantu para pengunjung, seperti pelayanan sopan, trampil dalam melaksanakan tugas dan pengetahuan memadai. Semakin tinggi jaminan yang diperlihatkan oleh para karyawan Taman Rusa Lamtanjong Kabupaten Aceh Besar, maka akan mempengaruhi kepuasan konsumen.

\section{Empati terhadap Kepuasan Konsumen}

Empati berpengaruh signifikan terhadap kepuasan pelanggan pelanggan wisatawan sebagai konsumen pengguna jasa wisata Lamtanjong Aceh Besar. Hasil temuan ini jugasama dengan hasil penelitian Assegaff (2009), Atmawati dan Wahyuddin (2007) serta Schroeder (2005). Empati merupakan kemudahan dalam melakukan hubungan, komunikasi yang baik, perhatian pribadi, dan memahami kebutuhan para konsumen oleh 
karyawan Taman Rusa Lamtanjong Kabupaten Aceh Besar, seperti perhatian perhatian kepada pelanggan, tanggungjawab keamanan dan kenyaman serta mengutamakan kepntingan pelanggan. Semakin tinggi empati yang diperlihatkan oleh para karyawan Taman Rusa Lamtanjong Kabupaten Aceh Besar, maka akan mempengaruhi kepuasan konsumen.

\section{Bukti Fisik terbadap Kepuasan Konsumen}

Bukti fisik berpengaruh signifikan terhadap kepuasan Konsumen pelanggan wisatawan sebagai konsumen pengguna jasa wisata Lamtanjong Aceh Besar. Hasil temuan ini mendukung penelitian Assegaff (2009), Atmawati dan Wahyuddin (2007) serta Schroeder (2005). Bukti fisik merupakan fisik dari Taman Rusa Lamtanjong Kabupaten Aceh Besar, seperti penataan interior dan eksterior yang baik, kerapian dan kebersihan ruangan serta teknologi yang digunakan canggih. Bukti fisik ini bisa mempengaruhi kenyamanan dan kelancaran dalam memberikan pelayanan kepada setiap pelanggan. Hal ini dapat dilihat dari sebagian besar responden yang menyatakan persetujuannya, artinya kondisi fisik pada Taman Rusa Lamtanjong Kabupaten Aceh Besar sudah sesuai dengan keinginan pelanggan. Semakin mendukung kondisi fisik di Taman Rusa Lamtanjong Kabupaten Aceh Besar, maka akan mempengaruhi kepuasan konsumen.

\section{Pengujian Hipotesis}

Untuk pengujian hipotesis, yang kemudian diuji dengan uji - $t$, hipotesis bisa dikemukakan sebagai berikut :

Ho: Tidak ada pengaruh yang signifikan antara variabel independen terhadap variabel dependen.

Ha: Ada pengaruh yang signifikan antara variabel independen terhadap variabel dependen.

Uji - $\mathrm{t}$ ini digunakan untuk membuktikan adanya pengaruh yang signifikan antara kualitas pelayanan yang dilihat keandalan, daya tanggap, jaminan dan empati bukti fisik terhadap kepuasan konsumen secara parsial. Ketentuan t tabel (Nurgiyantoro, dkk, 2004:192) :

$\alpha=0,05$ (satu sisi) $; \mathrm{n}-1=100-1=99$, maka $\mathrm{t}$ tabel $=1,660$

Ketentuan penerimaan hipotesis yaitu :

Ha ditolak bila sig. $>0,05$ atau thitung $<\mathrm{t}$ tabel
Ha diterima bila sig. $\leq 0,05$ atau thitung $>\mathrm{t}$ tabel.

Berdasarkan hasil pengolahan dengan program SPSS maka di dapat hasil uji - t, yang hasilnya dirangkum pada tabel berikut ini :

Tabel 5. Uji - $\mathrm{t}$

\begin{tabular}{lccc}
\hline \multicolumn{1}{c}{ Variabel } & $\begin{array}{c}\text { Hasil Uji }- \\
\mathrm{t}\end{array}$ & $\begin{array}{c}\mathrm{t} \\
\text { tabel }\end{array}$ & Sig. \\
\hline Kehandalan & 2,205 & 1,660 & 0,038 \\
Daya Tanggap & 3,245 & 1,660 & 0,016 \\
Jaminan & 2,708 & 1,660 & 0,021 \\
Empati & 2,404 & 1,660 & 0,010 \\
Bukti Fisik & 3,609 & 1,660 & 0,000 \\
\hline
\end{tabular}

Hasil uji - t dari keandalan, daya tanggap, jaminan, empati dan buktif fisik diperoleh nilai sig. lebih kecil $(<)$ dari 0,05 dan thitung $>\mathrm{t}$ tabel, sehingga hipotesis yang menyatakan bahwakeandalan, daya tanggap, jaminan, empati dan bukti fisik berpengaruh signifikan terhadap kepuasan konsumen secara parsial diterima.

\section{Kesimpulan dan Saran}

Hasil penelitian mengenai Faktor-faktor Yang Mempengaruhi Kepuasaan Pengguna Jasa Pada Wisata Taman Rusa Lam tanjong Aceh Besar, dapat dibuat beberapa kesimpulan sebagai berikut;

1. Persamaan regresi $\mathrm{Y}=3,270+0,075 \mathrm{X} 1+$ $0,373 \mathrm{X} 2+0,161 \mathrm{X} 3+0,129 \mathrm{X} 4+$ $0,837 X 5$ artinya semua variabel independen berpengaruh positif terhadap kepuasan konsumen, artinya apabila variabel independen naik, maka variabel dependenjuga meningkat, dan jika variabel independen turun, maka variabel dependenjuga menurun. Dari hasil koefesien regresi yang didapat menunjukkan, faktor bukti fisik (b5 $=0,837$ ) menjadi faktor terbesar yang mempengaruhi kepuasan konsumen, kemudian daya tanggap $(\mathrm{b} 2=0,373)$, jaminan $(\mathrm{b} 3=0,161)$, empati $(\mathrm{b} 4=0129)$, sementara kehandalan $(\mathrm{b} 1=0,075)$ menjadi faktor terendah yang mempengaruhi kepuasan konsumen.

2. Pengujian hipotesis secara parsial dari variabel independen signifikan, karenanilai signifikansi semua $<0,05$. Keandalan berpengaruh positif terhadapkepuasan pelanggan (uji - $\mathrm{t}=2,205$ dengan sig. $0,038<$ 
0,05). Daya tanggap berpengaruh positif terhadap kepuasan pelanggan (uji $-\mathrm{t}=$ 3,245 dengan sig. 0,016<0,05). Jaminan berpengaruh positifterhadap kepuasan pelanggan (uji - $\mathrm{t}=2$,708dengan sig. 0,021 $<$ 0,05). Empati berpengaruh positif terhadap kepuasan pelanggan (uji $-\mathrm{t}=$ 2,404 dengan sig. 0,010<0,05). Bukti fisik berpengaruh positif terhadap kepuasan konsumen (uji - $\mathrm{t}=3,609$ dengan sig. 0,000 $<0,05)$. Pengujian hipotesis secara simultan dari variabelindependen signifikan, karena nilai signifikansi $<0,05$. Keandalan, daya tanggap, jaminan, empati dan bukti fisik berpengaruh signifikan terhadap kepuasan konsumen.

Saran

Agar Wisata Taman Rusa Lamtanjong Kabupaten Aceh Besar lebih meningkatkan kepuasan konsumen maka perlu melakukan beberapa langkah sebagai berikut :

1. Jaminan mempunyai pengaruh terbesar terhadap kepuasan pelanggan. Indikator jaminan yang dominan adalah karyawan trampil dan mempunyaipengetahuan yang memadai. Untuk itu sebaiknya, karyawan tetapmempertahankan pola kerja selama ini, yaitu trampil dan senantiasa tetapmeningkatkan pengetahuannya yang salah satunya dapat diperoleh melaluiberbagai pelatihan yang diadakan oleh taman wisata.

2. Bukti fisik mempunyai pengaruh terbesar kedua terhadap kepuasan pelanggan. Indikator bukti fisik yang dominan adalah ruang interior dan eksterior dankebersihan ruang pelayanan. Untuk itu sebaiknya dalam melakukan penataaninterior dan eksterior tetapi rapi, seperti, kursi untuk tempat duduk pelangganditata secara per baris sehingga lebih rapi serta setiap ruangan selaludibersihkan setiap saat agar terlihat bersih dan menggunakan teknologi yanglebih canggih dalam memberikan pelayanan seperti penggunaan nomor antriansecara elektronik.

3. Daya tanggap mempunyai pengaruh terbesar ketiga terhadap kepuasan konsumen. Indikator daya tanggap yang dominan adalah kecepatan karyawandalam melayani kepentingan pelanggan serta kemampuan dan kemauankaryawan menjalin komunikasi. Untuk itu, sebaiknya karyawan lebih cepatdalam melayani konsumen, seperti perlu ada bagian customer service yang bertugas mengatasi keluhan atau permasalahan yang dihadapi konsumen sertabertugas memberikan informasi kepada konsumen yang berkaitan dengan pelayanan, dan karyawan yang bertugas di bagian customer serviceharus mempunyai kemampuan komunikasi yang baik sehingga bisa lancardalam berkomunikasi dengan konsumen.

\section{Daftar Pustaka}

Assegaff, M. (2009). Pengaruh Kualitas Pelayanan Terhadap Kepuasan Pelanggan (Studi Pada Perusahaan Penerbangan PT. Garuda Di Kota Semarang). Jurnal Ekonomi dan Bisnis, 10(2), 171-186.

Atmawati, R. (2010). Wahyuddin. 2007." Analisis Pengaruh Kualitas Pelayanan Terhadap Kepuasan Konsumen Pada Matahari Departement Store Di Solo Grand Mall". Jurnal Ekonomi dan Bisnis. Hal, 1-12.

Engel, James F, (2002). Custumer Behavior. Jilid satu edisi keenam. Binarupa Aksara, Jakarta.

Goetsch, D. L., \& Davis, S. B. (2002). Pengantar Manajemen Mutu 2. Jakarta: PT. Prenhalindo.

Hurriyati, Ratih (2005). Pengertian Jasa. Yogyakarta

Kotler, P., Keller, K. L., \& Bliemel, F. (2007). Marketing-management: Strategien für wertschaffendes Handeln. Pearson Deutschland GmbH.

Ma'ruf, (2005). Metode Pengumpulan Data. Jakarta : Erlangga.

Nurgiyantoro, (2004). Pengantar Metode Penelitian. Jakarta : PT. Rineka Cipta . 
Philip, K., \& Susanto, A. B. (2002). Manajemen Pemasaran di Indonesia: Analisis, perencanaan, implementasi dan pengendalian. Jakarta: Salemba Empat.

Saladin Djaslim, (2004). Pengertian Jasa. Yogyakarta.

Schroeder, J. E. (2005). Visual consumption (Vol. 4). Psychology Press.

Sekaran, U. (2006). Research method of business: A skill-building approach. Writing.

Sinaga, H.H., (2010). Analisis Kualitas Pelayanan pada SMK Antonius Semarang (Doctoral dissertation, UNIVERSITAS DIPONEGORO).
Suliyanto, D. (2007). Peranan Anggaran Sebagai Alat Perencanaan Manajemen Dalam Pembelian Bahan Baku (Doctoral dissertation, Universitas Kristen Maranatha).

Tjiptono, (2000). Manajemen Jasa. Yogyakarta: Andi.

Tjiptono, F. (2000). Manajemen jasa. Yogyakarta: Penerbit Andi.

Waryanto, Milifati, (2007). Teknik-Teknik Pengumpulan Data. Edisi Pertama. Jakarta : PT. Rineka Cipta. 